\title{
CCN2 (CTGF) Gene Polymorphism Is a Novel Prognostic Risk Factor for Cardiovascular Outcomes in Hemodialysis Patients
}

\author{
Mario Cozzolino ${ }^{a, c}$ Maria Luisa Biondi ${ }^{b}$ Elena Banfi ${ }^{b}$ Bruce L. Riser ${ }^{d}$ \\ Florjan Mehmeti $^{\mathrm{a}}$ Daniele Cusi ${ }^{\mathrm{a}, \mathrm{c}}$ Maurizio Gallieni ${ }^{c, \mathrm{e}}$

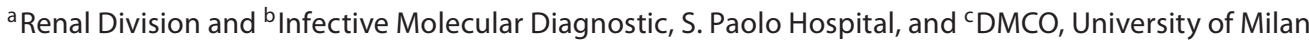 \\ School of Medicine, Milan, Italy; ${ }^{d}$ Department of Physiology and Biophysics, Rosalind Franklin University \\ of Medicine and Science, North Chicago, IIl., and Baxter Healthcare, Renal Division, McGaw Park, III., USA; \\ eNephrology and Dialysis Unit, Ospedale San Carlo Borromeo, Milan, Italy
}

\section{Key Words}

CCN2 - Connective tissue growth factor - Dialysis ·

Genetic polymorphism $\cdot$ Atherosclerosis, survival

\begin{abstract}
Background: The very high cardiovascular (CV) mortality and morbidity rates in hemodialysis (HD) patients are greatly related to atherosclerosis. CCN2 (connective tissue growth factor/CTGF) is a profibrotic factor that is secreted by endothelial cells, involved in atherogenesis, promoting fibroblast proliferation and matrix production. CCN2 protein is significantly increased in complicated fibrous plaques and enhances monocyte migration into atherosclerotic lesions. The aim of this study was to investigate a possible association between CCN2 gene polymorphism and CV morbidity and mortality in HD patients. Methods: $98 \mathrm{HD}$ patients, followed for 24 months, were genotyped for the common polymorphism on the CCN2 gene (G-945C). HD patient characteristics were: age $64 \pm 13$ years, males $64 \%$, diabetes $24 \%$, hypertension $62 \%$, smokers $38 \%$, dyslipidemia $28 \%$, all undergoing standard HD three times weekly. Results: All-cause mortality was not associated with CCN2 polymorphism (G-945C). In contrast, however, the GG genotype was strongly associated with CV mortality: OR 13 (1.49-155), $p=0.0048$. Interestingly, the GG genotype was also greatly associated with the
\end{abstract}

serious CV events of stroke and myocardial infarction in surviving HD patients: OR 13.3 (2.5-87.08), $p=0.0001$. Conclusions: We demonstrate for the first time that CCN2 gene polymorphism is a prognostic risk factor for $\mathrm{CV}$ morbidity and mortality in HD patients. These data may have important implications for better understanding the link between accelerated atherosclerosis and increased mortality in HD population.

Copyright $\odot 2010$ S. Karger AG, Basel

\section{Introduction}

Cardiovascular (CV) disease is the leading cause of mortality in dialysis patients [1]. The very high CV mortality and morbidity rates in this population are only partially explained by the high prevalence of traditional CV risk factors [2], which are classically related to atherosclerosis. The vascular changes observed in chronic kidney disease (CKD) patients consist not only of atherosclerosis but also of arteriosclerosis associated with both medial and intimal vascular calcification [3]. The degree of arterial stiffening and the extent of calcification are closely related [4], and both of these variables are strong and independent prognostic markers of all-cause and CV mortality in patients on hemodialysis (HD) $[5,6]$.

\section{KARGER}

Fax +41613061234 E-Mail karger@karger.ch www.karger.com
(C) 2010 S. Karger AG, Basel

0253-5068/10/0304-0272\$26.00/0

Accessible online at:

www.karger.com/bpu
Maurizio Gallieni, MD

Nephrology and Dialysis Unit - Ospedale San Carlo Borromeo

Via Pio Secondo 3, IT-20153 Milan (Italy)

Tel. +3902 4022 2445, Fax +39024022 2222

E-Mail maurizio.gallieni@fastwebnet.it 
The CCN family of genes was named after a number of gene products (Connective tissue growth factor, $\underline{\text { Cyr61/ }}$ Cef10, and Neuroblastoma overexpressed gene). CCN2 (formerly CTGF, or connective tissue growth factor) [7] is a profibrotic cytokine, discovered more than 15 years ago as a protein secreted by human endothelial cells [8]. Although strongly induced by transforming growth factor- $\beta$ (TGF- $\beta$ ) in many cell types and considered to be a downstream mediator of renal fibrosis, CCN2 can also be independently upregulated by TGF- $\beta$ [9-11]. Moreover, $\mathrm{CCN} 2$ promotes fibroblast proliferation and matrix production $[12,13]$.

Over the last 10 years, $\mathrm{CCN} 2$ has been shown to be involved in atherogenesis [14]. In fact, CCN2 mRNA is greatly expressed in vascular smooth muscle cells (VSMCs) of atherosclerotic blood vessels, but not in homologous normal arteries [15]. Furthermore, CCN2 protein expression is significantly increased in complicated atherosclerotic plaques compared with fibrous and more stable plaques and may enhance monocyte migration into atherosclerotic lesions, thus contributing to atherogenesis [16]. In addition, the finding of a strong chemotactic effect of CCN2 on bovine VSMCs in vitro may support the hypothesis that CCN2 plays an active role in the atherosclerotic process, by both promoting monocyte migration into the damaged vessels and inducing intimal angiogenesis [16].

Recently, Blom et al. [17] identified human CCN2 promoter polymorphisms. The expression of the gene encoding CCN2 has been found to be greatly upregulated in gene-expression-profiling studies of skin-biopsy specimens and of fibroblast cultures from skin from patients with systemic sclerosis. Fonseca et al. [18] demonstrated that the C allele at position -945 of the CCN2 promoter is critical for the normal repression of CCN2 transcription. However, a single substitution at this site in the $G$ allele (G-945) appears to result in increased transcription and expression of CCN2, and is significantly associated with susceptibility to systemic sclerosis. Moreover, the CCN2 gene polymorphism (G-945) was associated with higher degree of calcification and fibrosis in 187 stenotic aortic valves excised from normal renal function patients [19].

Others and we have also shown that renal CCN2 mRNA and urinary secreted protein is upregulated in both animal models of diabetic nephropathy and in CKD patients, indicating a role for abnormal production in early progression $[20,21]$. Collectively, this suggested to us that an abnormal CCN2 activity, driven at least in part by a CCN2 polymorphism, might be critically important to the increased CV morbidity and mortality observed in dialysis patients. We investigated this possibility in the present prospective study of patients receiving dialysis.

\section{Materials and Methods}

\section{Patients}

Patients were recruited among the prevalent HD population at San Paolo Hospital, Milan, Italy. All the 98 recruited patients were Caucasian adults aged $64 \pm 13$ years, $64 \%$ were male, with a median dialysis vintage of 85 months (range 9-454 months). All patients were treated by standard bicarbonate dialysis for $4 \mathrm{~h}, 3$ times weekly. Information on concomitant hypertension, diabetes mellitus and dyslipidemia was obtained from hospital charts; patients were investigated concerning their smoking status and previous $\mathrm{CV}$ events (myocardial infarction, angina, stroke, transient ischemic attack, pulmonary thromboembolism). Once enrolled, patients were followed up prospectively for 2 years.

Blood pressure was measured at the beginning of the dialysis session. Hypertension was defined as systolic blood pressure $(\mathrm{SBP}) \geq 140 \mathrm{~mm} \mathrm{Hg}$ and diastolic blood pressure $(\mathrm{DBP}) \geq 80$ $\mathrm{mm} \mathrm{Hg}$, or normal blood pressure in patients treated with one or more antihypertensive drugs. Patients were treated with a variety of such drugs, including $\beta$-blockers, ACE inhibitors, angiotensin receptor antagonists, diuretics, and calcium-channel blockers. Data were collected about concomitant pharmacological therapy.

Diabetes was defined as fasting blood glucose levels $\geq 126 \mathrm{mg} /$ dl. Dyslipidemia was defined as serum LDL cholesterol levels $\geq 110 \mathrm{mg} / \mathrm{dl}$ in at least three measurements within 1 year. Smoking was defined as current use of cigarettes, with $>10$ cigarettes daily, for more than 10 years.

Blood samples for measurement of routine biochemical parameters were drawn from each patient before the beginning of the first HD treatment of the week. Serum levels are expressed as the mean of the available regular tests, at least three measurements in 1 year.

\section{Identification of CCN2 Gene Polymorphisms}

Patients were genotyped for the common polymorphism on the CCN2 gene (G-945C). Whole blood $(3 \mathrm{ml})$ from patients and healthy volunteers was collected into potassium EDTA-containing tubes. DNA was prepared with the Istagene Matrix extraction kit (Bio-Rad Laboratories). The polymerase chain reaction (PCR) for CCN2 was performed in a total volume of $25 \mu \mathrm{l}$ with $5 \mu \mathrm{l}$ of extracted genomic DNA, $100 \mu \mathrm{M}$ of dATP, dGTP, dTTP, and $\mathrm{dCTP}, 1.5 \mathrm{mmol} / \mathrm{l}$ of $\mathrm{MgCl}_{2}$, and $1 \mathrm{U}$ of Taq polymerase. The two primers, forward and reverse, were each used at a concentration of $80 \mathrm{nM}$, and were designed with Primer Express software. The CCN2 primer sequence was: forward: 5'-ATTGATGGCCACT CCTCCCTTGTCCTTGCC-3'; reverse: 5'-GGCAAGGACAAG GGAGGAGTGGCCATCAAT-3'. The PCR was started within 5 min of incubation at $94^{\circ} \mathrm{C}$ to activate the enzyme, and was followed by 35 cycles $(20 \mathrm{~s} \mathrm{each})$ at $94^{\circ} \mathrm{C}, 55^{\circ} \mathrm{C}$, then $30 \mathrm{~s}$ at $72^{\circ} \mathrm{C}$. The amplification was verified on an agarose gel (2\%) followed directly by sequencing with an automatic sequencer in fluorescent DNA capillary electrophoresis (ABI Prism 310; Applied Biosystems). 


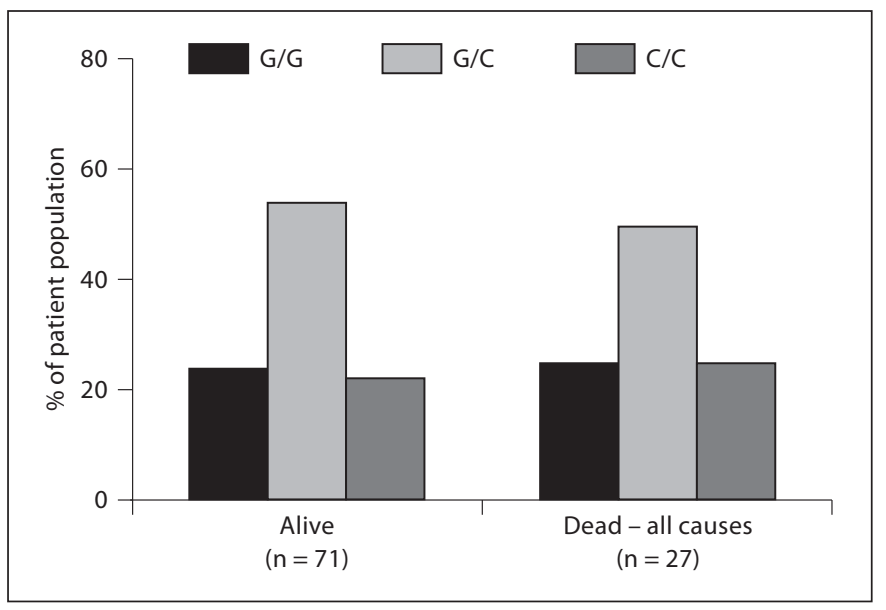

Fig. 1. CCN2 gene polymorphism does not associate with allcause mortality at 2 years of follow-up. In both alive and dead HD patients, the distribution of CCN2 gene did not show a significant association with mortality rate.

Statistical Analyses and Ethics

Differences between groups were examined by $\chi^{2}$ test. Odds ratios (approximate relative risk) were calculated as an index of the association of the G-945C genotype with each phenotype (GG, GC, CC). For each odds ratio, two-tailed probability values and $95 \%$ confidence intervals were calculated.

The study was approved by the Ethics Committee of San Paolo Hospital, Milan, Italy. All patients gave their informed consent in writing before they were submitted to any procedures related to the study.

\section{Results}

A total of $98 \mathrm{HD}$ patients were included in the study. Their main characteristics are summarized in table 1 . No patients were lost or transplanted during follow-up. We first examined the relationship between all-cause mortality and CCN2 polymorphism (G-945C) (table 2; fig. 1). The presence of the CCN2 polymorphism (GG, or GC) was not different between survivors and expired patients when considering death by any cause. In contrast, however, the GG genotype was associated with CV mortality: OR 13 (1.49-155), $\mathrm{p}=0.0048$ (table 2; fig. 2). Most patients dying from $\mathrm{CV}$-related causes were from the GG group $(\mathrm{p}<0.05)$. In comparison, only a small proportion of $\mathrm{C} / \mathrm{C}$ genotype patients died from CV-related death. The non$\mathrm{CV}$-related death group was made up mostly of a combination of patients bearing a CCN2 CC or GC genotype.

Interestingly, the GG genotype was also greatly associated with the serious CV events of stroke and myocardial infarction in surviving HD patients: OR 13.3 (2.5-87.08),

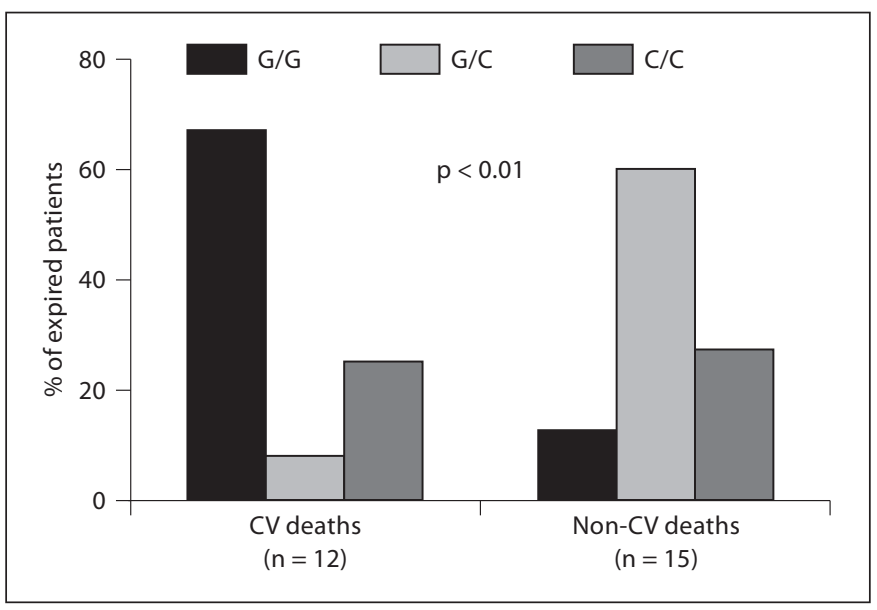

Fig. 2. CCN2 gene polymorphism $(\mathrm{G} / \mathrm{G})$ is associated with $\mathrm{CV}$ mortality.

Table 1. Characteristics of the study population

\begin{tabular}{lc}
\hline Characteristic & $\begin{array}{l}\text { HD } \\
\text { patients }(\mathrm{n}=99)\end{array}$ \\
\hline Male gender, \% & 64 \\
Age (mean \pm SD), years & $64 \pm 13$ \\
Diabetes mellitus type 2, \% & 24 \\
Hypertension ${ }^{\mathrm{a}}, \%$ & 62 \\
Smokers, \% & 38 \\
Dyslipidemiab $\%$ & 28 \\
C-reactive protein (mean \pm SD), mg/dl & $7.54 \pm 9.36$ \\
Albumin (mean \pm SD), g/dl & $4.09 \pm 0.31$ \\
History of CV events, \% & 62 \\
iPTH (mean \pm SD), pg/ml & $274 \pm 254$ \\
URR, \% & $78 \pm 1$ \\
HD vintage (mean \pm SD), months & $85 \pm 65$
\end{tabular}

${ }^{\text {a }}$ Hypertension was defined as SBP $\geq 140 \mathrm{~mm} \mathrm{Hg}$ or DBP $\geq 80$ $\mathrm{mm} \mathrm{Hg}$, or normal blood pressure in patients treated with one or more antihypertensive drugs including $\beta$-blockers, ACE inhibitors, angiotensin receptor antagonists, diuretics, and calciumchannel blockers. ${ }^{\mathrm{b}}$ Dyslipidemia was defined by serum LDL cholesterol levels $\geq 110 \mathrm{mg} / \mathrm{dl}$ in at least three measurements in 1 year.

$\mathrm{p}=0.0001$ (table 2; fig. 3). Among the group experiencing these serious $\mathrm{CV}$-related events, the vast majority had the GG genotype (8/11 or $73 \%$, compared to $10 / 60$ or $17 \%$ of GG genotype patients in the group with no CV events). Conversely, only $3 / 11$ (27\%) patients with a major CV event had the CG or CC genotypes, compared to 50/60 or $83 \%$ in the group with no CV events (table 2). 
Table 2. CCN2 polymorphism distribution in dialysis patients according to overall survival, CV mortality and occurrence of major $\mathrm{CV}$ events (stroke and myocardial infarction)

\begin{tabular}{|c|c|c|c|c|c|c|}
\hline \multirow[t]{2}{*}{$\begin{array}{l}\text { CCN2 } \\
\text { poly- } \\
\text { morphism }\end{array}$} & \multicolumn{2}{|c|}{$\begin{array}{l}\text { All-cause } \\
\text { mortality } \\
(\mathrm{p}=\text { n.s. })\end{array}$} & \multicolumn{2}{|c|}{$\begin{array}{l}\text { CV mortality } \\
(p<0.01)\end{array}$} & \multicolumn{2}{|c|}{$\begin{array}{l}\text { CV events } \\
(p=0.0001)\end{array}$} \\
\hline & $\begin{array}{l}\text { alive } \\
\text { (71) }\end{array}$ & $\begin{array}{l}\text { dead } \\
(27)\end{array}$ & $\begin{array}{l}\text { CV death } \\
\text { (12) }\end{array}$ & $\begin{array}{l}\text { non-CV } \\
\text { death (15) }\end{array}$ & $\begin{array}{l}\text { yes } \\
\text { (11) }\end{array}$ & $\begin{array}{l}\text { no } \\
(60)\end{array}$ \\
\hline $\mathrm{G} / \mathrm{G}$ & 17 & 7 & 8 & 2 & 8 & 10 \\
\hline $\mathrm{G} / \mathrm{C}$ & 38 & 14 & 1 & 9 & 2 & 35 \\
\hline $\mathrm{C} / \mathrm{C}$ & 16 & 6 & 3 & 4 & 1 & 15 \\
\hline
\end{tabular}

The C allele at position -945 of the CCN2 promoter is critical for the normal repression of CCN2 transcription; a single substitution at this site in the G allele (G-945) appears to result in increased transcription and expression of CCN2, and is significantly associated with susceptibility to systemic sclerosis.

\section{Discussion}

In this study, we demonstrate for the first time that $\mathrm{CCN} 2$ gene polymorphism might be a novel prognostic risk factor for $\mathrm{CV}$ morbidity and mortality in $\mathrm{HD}$ patients.

CCN2 (CTGF) is a matricellular protein characterized by a cysteine-rich, heparin-binding structure. Extensive studies have shown that $\mathrm{CCN} 2$ mirrors many of the effects of TGF- $\beta$ on skin fibroblasts, and other cells, such as stimulation of extracellular matrix, cell proliferation, and integrin expression, likely as a downstream modulator $[8$, 9]. Moreover, it has been demonstrated that $\mathrm{CCN} 2$ can promote endothelial cell growth and adhesion through a stimulation of macrophage migration and survival, suggesting an implication in endothelial cell function, angiogenesis and atherosclerosis progression [22]. Interestingly, CCN2 was initially identified in the culture supernatant of vascular endothelial cells [8] and it is an important inducer of development and regeneration of mesenchymal tissues including bone, cartilage and blood vessels.

Since its initial discovery, CCN2 has been widely known as a profibrotic factor that is involved in a variety of fibrotic disorders. CCN2 is associated with systemic sclerosis, pulmonary fibrosis, diabetic renal fibrosis, liver cirrhosis, pancreatic fibrosis, biliary atresia, atherosclerosis, and myocardial fibrosis [8]. Since CCN2 has a positive role in wound healing and mesenchymal tissue regeneration, the fibrotic changes observed in those diseases may be regarded as a result of deregulated regeneration of corresponding tissues [8]. VSMCs greatly ex-

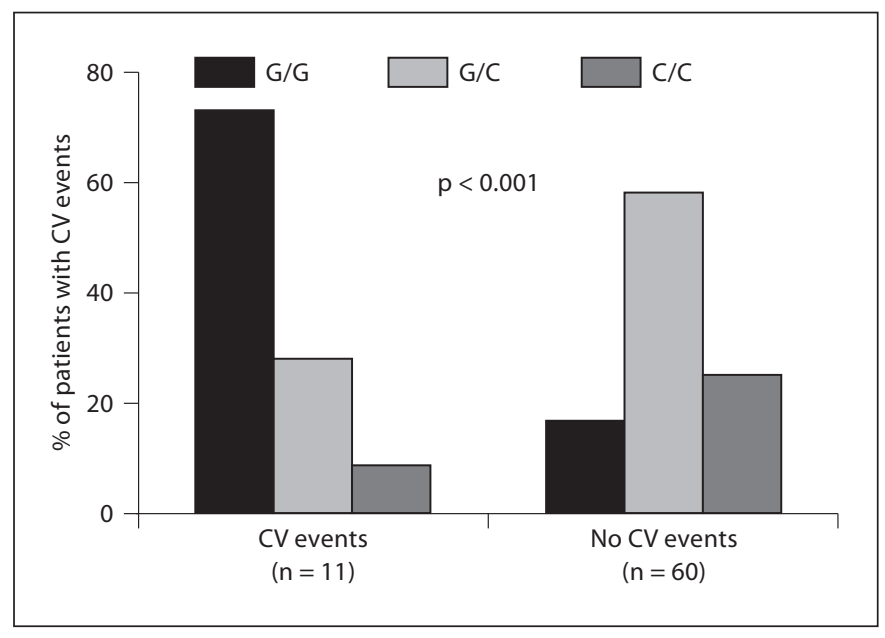

Fig. 3. CCN2 gene polymorphism $(\mathrm{G} / \mathrm{G})$ is associated with major CV events.

press both CCN2 mRNA and protein in atherosclerotic conditions and calcified plaques, compared to normal arterial vessels $[15,16]$. For this reason, over the last decade a central role in the pathogenesis of atherogenesis has been recognized for CCN2 [14].

It should be borne in mind that numerous factors contribute toward the marked arterial calcification observed in HD patients: all the 'classic' risk factors for atherosclerosis plus CKD-specific risk factors, such as duration of dialysis, uremic toxins, inflammation, and increased serum levels of calcium, phosphate and PTH [5].

In our study, we first examined the relationship between all-cause mortality and CCN2 polymorphism (G945C) (fig. 1). The presence of the CCN2 polymorphism (GG, or GC) was not different between survivors and expired patients when considering death by any cause. Interestingly, only the GG genotype was strongly associated with CV mortality and with higher incidence of strokes and myocardial infarction in surviving HD patients (fig. 2, 3). No other data have been published on the human CCN2 promoter polymorphisms in either CKD or HD populations.

In previous studies we reported that other genotypes of inhibitory proteins involved in the pathogenesis of vascular calcification do (matrix Gla protein) or do not (fetuin-A) associate with mortality risk in HD patients [23, 24]. More recently, we demonstrated that HD patients have a different distribution of matrix metalloproteinases (MMPs) 1 and 3 gene polymorphisms as compared to the normal population [25]. MMPs are a family of en- 
zymes involved in the biology of extracellular matrix and in atherogenesis. Consequently, altered polymorphisms of the MMP1 and MMP3 genes might be considered a negative prognostic factor for CV morbidity and mortality in HD population [25].

Thus, the finding of a new gene product influencing $\mathrm{CV}$ morbidity and mortality in the dialysis population is clinically relevant [26], as it adds useful information for understanding the complex interplay of genetic and environmental factors that ultimately determine occurrence of CV disease. Specifically, our data may have important implications for better understanding the link between accelerated atherosclerosis and increased mortality in HD population, justifying the design of a prospective study on the role of CCN2 gene polymorphism in determining $\mathrm{CV}$ outcomes in HD patients. This might help to clarify the pathogenesis of increased risk of ectopic calcification and $\mathrm{CV}$ events in patients with renal failure.

\section{Acknowledgements}

This research was supported in part by an investigator supported trial grant from Shire Pharmaceuticals (M.C.) and in part by Ingenious Hypercare LSHM-CT-2006-037093 (D.C.), by HYPERGENES grant HEALTH-F4-2007-201550 (D.C.).

\section{References}

1 Foley RN, Parfrey PS: Clinical epidemiology of cardiovascular disease in chronic renal disease. Am J Kidney Dis 1998;32(suppl 3):S112-S119.

$\checkmark 2$ Zoccali C, Tripepi G, Mallamaci F: Predic tors of cardiovascular death in ESRD. Semin Nephrol 2005;25:358-362.

-3 Longenecker JC, Coresh J, Powe NR, et al: Traditional cardiovascular disease risk factors in dialysis patients compared with the general population: the CHOICE study. J Am Soc Nephrol 2002;13:1918-1927.

-4 London GM: Cardiovascular calcifications in uremic patients: clinical impact on cardiovascular function. J Am Soc Nephrol 2003; 14:S305-S309.

5 Cozzolino M, Brancaccio D, Gallieni M, Slatopolsky E: Pathogenesis of vascular calcification in chronic kidney disease. Kidney Int 2005;68:429-436.

-6 Cozzolino M, Mazzaferro S, Pugliese F, Brancaccio D: Vascular calcification and uremia: what do we know? Am J Nephrol 2008;28:339-346

-7 Brigstock DR, Goldschmeding R, Katsube KI, et al: Proposal for a unified CCN nomenclature. Mol Pathol 2003;56:127-128.

$\checkmark 8$ Riser, BL, Najmabadi F, Perbal B, et al: CCN3 (Nov) is a negative regulator of CCN2 (CTGF) and a novel endogenous inhibitor of the fibrotic pathway in an in vitro model of renal disease. Am J Pathol 2009;174:17251734 .

-9 Riser BL, DeNichilo M, Cortes P, et al: Regulation of connective tissue growth factor activity in cultured rat mesangial cells and its expression in experimental diabetic glomerulosclerosis. J Am Soc Nephrol 2000;11:2538.
10 Leask A, Denton CP, Abraham DJ: Insights into the molecular mechanism of sustained fibrosis: the role of connective tissue growth factor. J Invest Dermatol 2004;122:1-6.

-11 Cooker LA, Peterson D, Rambow J, et al: TNF- $\alpha$, but not IFN- $\gamma$, regulates $\mathrm{CCN} 2$ (CTGF), collagen type I, and proliferation in mesangial cells: possible roles in the progression of renal fibrosis. Am J Physiol Renal Physiol 2007;293:F157-F165.

12 Shi-wen X, Pennington D, Holmes A, et al: Autocrine overexpression of CTGF maintains fibrosis: RDA analysis of fibrosis genes in systemic sclerosis. Exp Cell Res 2000;259: 213-224.

13 Brigstock DR, Steffen CL, Kim GY, et al: Purification and characterization of novel heparin-binding growth factors in uterine secretory fluids. Identification as heparinregulated MR 10,000 forms of connective tissue growth factor. J Biol Chem 1997;272: 20275-20282.

14 Oemar BS, Werner A, Garnier JM, et al: Human connective tissue growth factor is expressed in advanced atherosclerotic lesions. Circulation 1997;95:831-839.

15 Oemar BS, Luscher TF: Connective tissue growth factor. Friend or foe? Arterioscler Thromb Vasc Biol 1997; 17:1483-1489.

16 Cicha I, Yilmaz A, Klein M, et al: Connective tissue growth factor is overexpressed in complicated atherosclerotic plaques and induces mononuclear cell chemotaxis in vitro. Arterioscler Thromb Vasc Biol 2005;25:10081013.

17 Blom IE, van Dijk AJ, de Weger RA, et al: Identification of human CCN2 (connective tissue growth factor) promoter polymorphisms. J Clin Pathol Mol Pathol 2001;54 192-196.

18 Fonseca C, Lindhal GE, Ponticos M, et al: A polymorphism in the CTGF promoter region associated with systemic sclerosis. N Engl J Med 2007;357:1210-1220.
19 Ortlepp JR, Schimtz F, Mevissen V, et al: The amount of calcium-deficient hexagonal hydroxyapatite in aortic valves is influenced by gender and associated with genetic polymorphisms in patients with severe calcific aortic stenosis. Eur Heart J 2004;25:514-522.

20 Riser BL, Cortes P, DeNichilo M, et al: Urinary CCN2 (CTGF): as a possible predictor of diabetic nephropathy: preliminary report. Kidney In 2003;64:451-458.

21 Tam F WK, Riser BL, Meeran K, et al: Urinary monocyte chemoattractant protein-1 (MCP-1) and connective tissue growth factor (CCN2) as prognostic markers for progression of diabetic nephropathy. Cytokine 2009; 47:37-42.

22 Brigstock DR: Regulation of angiogenesis and endothelial cell function by connective tissue growth factor (CTGF) and cysteinerich 61 (CYR61). Angiogenesis 2002;5:153165.

23 Cozzolino M, Biondi ML, Galassi A, et al: Gene polymorphisms and serum $\alpha_{2}$-Heremans-Schmid levels in Italian haemodialysis patients. Am J Nephrol 2007;27:639-642.

$>24$ Brancaccio D, Biondi ML, Gallieni M, et al: Matrix GLA protein gene polymorphisms: clinical correlates and cardiovascular mortality in chronic kidney disease patients. Am J Nephrol 2005;25:548-552.

25 Cozzolino M, Biondi ML, Galassi A, et al: Matrix metalloproteinase-1 and matrix metalloproteinase-3 gene promoter polymorphisms are associated with mortality in haemodialysis patients. Nephrol Dial Transplant 2009;24:2207-2212.

-26 Cozzolino M, Biondi ML, Galassi A, Cusi D, Brancaccio D, Gallieni M: Vascular calcification and cardiovascular outcome in dialysis patients: the role of gene polymorphisms. Blood Purif 2010;29:347-351. 